\title{
Els objectes naturals i la identitat nacional. Les muntanyes a Catalunya i al Quebec ${ }^{1}$
}

\section{Éric Darier}

Université du Québec à Montréal \& Greenpeace

Eric.darier@yto.greenpeace.org

\section{Joan David Tàbara}

Universitat Autònoma de Barcelona. Institut de Ciència i Tecnologia Ambientals 08193 Bellaterra (Barcelona) Spain

Joandavid.tabara@uab.es

\section{Resum}

Existeix un estret lligam entre les reivindicacions nacionalistes i la reverència per les muntanyes per part d'aquelles nacions sense estat que no han pogut consolidar les seves fronteres o institucions nacionals d'una altra manera. Les muntanyes han servit de refugi espiritual i de metàfora simbòlica per representar la identitat i els significats col-lectius d'aquestes nacions sense estat $i$, a la vegada, les primeres demandes per la conservació d'espais feren molt sovint recurs als discursos nacionalistes. Aquest és el cas de Montserrat, símbol de la identitat catalana i on es va redactar el primer pla per la creació d'un parc nacional a l'Estat espanyol, malgrat que aquest projecte finalment no va reeixir. Al Quebec, és possible observar-hi un fenomen similar amb les Laurentides. Utilitzem una aproximació comparativa entre els dos contextos i el marc interpretatiu de Bruno Latour per entendre aquest procés d'hibridació tan peculiar que es produeix entre natura i nació.

Paraules clau: nacionalisme, conservació de la natura, Bruno Latour, Catalunya, Quebec.

Resumen. Los objetos naturales y la identidad nacional. Las montañas en Cataluña y Quebec

Existe un estrecho vínculo entre las reivindicaciones nacionalistas y la reverencia por las montañas por parte de aquellas naciones sin estado que no han podido consolidar sus fronteras o instituciones nacionales de otra manera. Las montañas han servido de refugio espiritual y de metáfora simbólica para representar la identidad y los significados colectivos de estas naciones sin estado y, a la vez, las primeras demandas para la conservación de espacios muy a menudo hicieron uso de los discursos nacionalistas. Éste es el caso de Montserrat, símbolo de la identidad catalana y lugar donde se redactó el primer plan para la creación de un parque nacional a nivel de Estado español, a pesar de que éste no llegó a tener éxito. En Québec, es posible observar un fenómeno similar con Les Laurentides. Utilizamos un

1. Aquest article fou originàriament presentat al II Congrés Català de Sociologia, celebrat a Lleida els dies 20 i 21 de març de 1999, amb el titol: Natural objects and National Identity. Mountains in Catalonia and Quebec. Traduït per Feliu López i Gelats. Aquesta traducció ha rebut l'ajut del Departament de Sociologia de la Universitat d'Otawa, Canadà, a través del professor Raymond Murphy. 
enfoque comparativo entre ambos contextos y el marco interpretativo de Bruno Latour para entender este proceso de hibridización tan peculiar que se produce entre naturaleza y nación.

Palabras clave: nacionalismo, conservación de la naturaleza, Bruno Latour, Catalunya, Quebec.

\section{Abstract. Natural objects and national identity. Mountains in Catalonia and Quebec}

There is a close relationship between nationalist claims and the expression of social reverence for mountains by those nations without state which have not been able to consolidate formally their borders or national institutions. Mountains have served as spiritual refuge and as a symbolic metaphor to represent the identity and the collective meanings of those nations without state, while at the same time, claims for conservation, have very often made use of nationalist discourses. This is the case of Montserrat, a mountain range which symbolises the Catalan nation and in which the first plan for the creation of a national park at a state level was written, although it did not succeed. In Quebec a similar phenomena can be observed with the Les Laurentides. We use a comparative approach and the interpretative framework of Bruno Latour to understand this peculiar process of hybridisation between nature and nation.

Key words: nationalism, nature conservation, Bruno Latour, Catalonia, Quebec.

\section{Sumari}

1. Introducció. Híbrids i reificació

2. Reificació u: nacionalismes

3. Reificació dos: natures

4. Hibridació a les Laurentides: el coureur de bois del Quebec
5. Hibridació a les muntanyes:

Montserrat i Catalunya

6. Conclusió

Bibliografia

\section{Introducció. Híbrids i reificació}

Els objectes naturals i les identitats nacionals es poden considerar una categoria híbrida irreductible a les categories analítiques habituals de «natura» $\mathrm{i}$ «nació». En aquest article, partim d'una postura epistemològica particular, que reconeix la utilitat heurística de les categories híbrides no reductibles ni a "construccions socials» ni a argumentacions biofísiques «realistes». Abans d'explicar el que intentem aconseguir, volem fer dos advertiments importants. En primer lloc, no pretenem simplement discutir la posició dels discursos al voltant d'objectes «naturals» específics (per exemple: la «muntanya», el «bosc», etc.) a través del prisma de presumptes identitats nacionals no problematitzades. En segon lloc, no pretenem simplement discutir el paper del «nacionalisme» en la construcció i/o «representació» d'objectes «naturals» específics, presos exclusivament com a artefactes culturals. Per contra, considerem que, en determinats contextos socials, les dues categories —els objectes naturals i les identitats 
nacionals- esdevenen com a efectes d'un procés analític continu de reificació —o de "purificació», si fem servir la terminologia de Bruno Latour (1993) — fruit de lluites específiques al voltant del "poder de definir» categories epistemològiques i ontològiques concretes (Haraway, 1991; Darier, 1995; 1999; 2005). L'objectiu de Bruno Latour és el de posar a la vista la importància d'allò que no és humà com a «actant» en la producció de la realitat. De fet, Latour el que vol és remarcar la incapacitat teòrica de separar nítidament la contribució humana i no humana en la producció de la realitat. Aquesta "realitat» mateixa és el resultat del procés d'hibridació entre no humans i humans en denses i complexes xarxes de relacions humanes i no humanes. A fi d'il.lustrar-nos aquests processos, Latour explica que les suposicions actuals sobre la forta distinció entre "cultura i natura» és, en gran mesura, més aviat el fruit d'un procés continu de "purificació» analítica (Latour, 1993) que no pas una descripció acurada.

El nostre objectiu aquí és el d'explorar les possibilitats d'anar més enllà del debat "construccionista i realista", bo i fent servir alguns dels conceptes teòrics d'hibridació de Latour (Michael, 1996; Demeritt, 1995; 2002). En sociologia del medi ambient, el realisme sovint s'associa a aquelles posicions que entenen els problemes ambientals i els objectes naturals com a realitats indiscutibles i abastables de forma no necessariament problemàtica, per exemple, a través del coneixement científic; mentre que el socialconstruccionisme concep els problemes ambientals i l'entorn ambiental com a "creacions socials». No obstant això, la nostra hipòtesi de partida és que el concepte de Latour sobre els híbrids és particularment prometedor per superar aquest dualisme. I, com a metodologia, utilitzem l'estudi comparatiu entre els casos de Catalunya i el Quebec per contrastar aquesta hipòtesi. El concepte d'híbrids reclama que «objectes» específics són el fruit d'efectes mutus, contingents, inestables, complexos i continus, entre allò que podria ser entès com a categories «socioculturals» $\mathrm{i}$ «naturals». En particular, una «muntanya» és molt més que l'agregació de fets físics o dades geològiques positivistes proporcionades per científics. Al mateix temps, una «muntanya» també és molt més que una sèrie de valors "culturals» $\mathrm{i}$ «simbòlics» (Freudenburg $\mathrm{i}$ altres, 1995). A més a més, la idea d'allò que constitueix la «identitat nacional» (per exemple: ser català o quebequès) i la raó de la seva existència no pot ser reduïda simplement a explicacions racionals (per exemple: les anàlisis de cost $\mathrm{i}$ benefici o les reinterpretacions històriques), ni tampoc a un subjectivisme col-lectiu.

Massa sovint, els raonaments socials que han considerat les explicacions d'autonomia relativa per a les identitats culturals han estat o bé menyspreades o bé donades per suposat a l'hora d'analitzar la localització de les formes culturals. Més sorprenent ha estat el nou despertar de reclamacions nacionalistes que apareixen fins i tot al cor mateix dels estats nació més consolidats i que aparentment no sembla que tingui una explicació clara. En el present context d'interculturalisme global, la qüestió sobre com i per quines raons respon la permanència d'afirmacions col-lectives lligades al territori que resisteixen a qualsevol 
intent de desespacialització és recurrent. Noves reclamacions i representacions localitzades espacialment es barregen amb unes d'antigues, com a conseqüència de continus i complexos processos geoculturals, que poden ser parcialment descrits, però que a la vegada són rarament compresos en profunditat. Tanmateix, acceptar l'existència ontològica i, en gran mesura, certa independència de les expressions col-lectives culturals i espacials, la naturalesa essencial de la qual està més enllà de modificacions individuals intencionades, no implica que aquestes realitats siguin ni estàtiques ni no exposades al canvi. Tampoc aquesta manera de concebre la cultura ens exclou de la possibilitat de dur a terme una anàlisi comparativa, tot i que limitada, d'aquests processos particulars que tenen lloc a les interseccions entre el lloc (o la natura) i la cultura. De fet, aquesta és una zona particular de totes dues categories i realitats, que es genera i es reprodueix entre el que és imaginari i el que és real, allà on certes cultures finalment localitzen les seves referències còsmiques i expressen la culminació de les seves singularitats essencials. Aquests llocs geonacionals són tan construïts socialment com ho són també les essències que suposadament representen. I, a la vegada, aquestes peculiaritats culturals són tan reals com ho són els llocs que esdevenen l'objecte de les seves representacions nacionals. Aquest procés de reafirmació cultural i espacial, i la reificació generada, que aquí entenem que consisteix en un tipus d'hibridació específica, és particularment agut en el cas de les anomenades nacions sense estat.

Un cop delimitat el marc interpretatiu del nostre objecte, en aquest article ens limitarem a il.lustrar alguns dels processos d'hibridació i reificació entre natura i cultura en dos espais "geogràfics» específics on la identitat «nacional» és problematitzada o reafirmada a través de la natura: a Catalunya i al Quebec. Per tal de dur a terme aquesta tasca, limitarem encara més la nostra recerca a les «muntanyes», una categoria híbrida particularment productiva en totes dues localitzacions, tant pel que fa a la producció d' «identitat nacional» com a la d'«objectes naturals». Òbviament, pretenem també reconèixer i il.lustrar l'heterogeneïtat i la complexitat dels processos híbrids que podrien també incloure unes altres categories que, en temes ambientals, han abordat aspectes com ara el "gènere» i la «masculinitat» (per exemple: Demeritt, 1995) o les pràctiques «ecoreligioses» (per exemple: Giner i Tàbara, 1998). Abans d'embarcar-nos, però, en aquesta tasca, és necessari explicar la tria dels dos estudis de cas entre el vast cos de literatura de què disposem sobre «nacionalisme». Examinarem també breument les semblances i les diferències entre alguns dels objectes «naturals» en els estudis de cas escollits, encara que ho farem principalment des d'un punt de vista «realista». Esperem ser capaços de demostrar que els objectes triats no poden ser entesos simplement, ja sigui bé com a purament «naturals» o bé, com alguns autors defensen (Macnaghten i altres, 1995), com a només "construïts socialment». En efecte, i tal com ha demostrat correctament Stephen Daniels (1993), «la identitat nacional pot prendre moltes formes — si és modulada per uns altres tipus d'identitat cultural, de classe, de gènere, de raça i de religió, com ara unes altres formes d'identitat cultural i geogràfica [...] ja que, com A. D. Smith (1991) remarca, cap identitat nacional és 
caracteritzada conscientment sols com una herència històrica o com una herència geogràfica» (Daniels, 1993: 4-5; vegeu també Urry, 1995: 228).

\section{Reificació u: nacionalismes}

Hi ha una extensa literatura $\mathrm{i}$ un interès relativament renovat sobre el «nacionalisme», especialment en el context de les «nacions sense estat» i/o dels «estats sense nació» (per exemple: Guibernau, 1996; Guibernau i altres, 1997; Llobera, 1994; Van Horne, 1997). Hi ha nombrosos anàlisis i comentaris sobre cadascun dels nostres estudis de cas: Catalunya (per exemple: Balcells, 1996; De Riquer, 1990; Giner, 1980; Guibernau, 1996, 2004, Payne, 1991; Llobera, 1989; McRoberts, 2002; Pi-Sunyer, 1985), el Quebec (per exemple: Breton, 1996; Clift, 1987; Coleman, 1984; Gagnon i altres, 1990, 2001, 2003; McRoberts, 1988; Létourneau, 1994, 2004a, 2004b; Levine, 1997; Turgeon i altres, 1997). Però hi ha pocs estudis comparatius de "nacions sense estat», especialment entre «nacions sense estat» obvis com Catalunya i el Quebec (per exemple: Guibernau, 1999, 1997; Keating, 1996, 2001; Temblay i altres, 1990). En tots dos casos, la identitat nacional és sovint definida en oposició a una «altra» gran entitat («Espanya» en el cas de Catalunya i la "resta del Canadà» en el cas del Quebec). Com a resposta a l'experiència traumàtica que representaren els règims feixistes i nazi des dels anys 1920 fins a mitjan 1940 (fins al 1975 a Espanya), acadèmics sobre «nacionalisme» han intentat tornar a explicar la persistència del «nacionalisme» en el context d'un règim democràtic, de modernització econòmica i de globalització. No hi ha, però, cap estudi comparatiu que lligui els aspectes naturalnacionals dels dos contextos socials triats en la present investigació.

Els acadèmics tendeixen a caracteritzar el nacionalisme bé com un fenomen «ètnic» o bé com un procés «civicocultural». La primera caracterització es basa en la premissa que l' «etnicitat» —entesa com una categoria «natural» no problematitzada - és allò que caracteritza la pertinença i la no pertinença a la categoria «nacional». Òbviament, aquesta modalitat de nacionalisme ètnic ha estat subjecta a moltes crítiques, ja que s'ha adduït que fins i tot podria conduir cap a la neteja ètnica, tal com la que dugueren a terme els nazis. Davant d'això, el "federalisme liberal» sovint s'entén com una possible sortida dels estats per acomodar les seves institucions a realitats plurinacionals (Requejo, 2000). Per contra, el nacionalisme «civicocultural» defineix el fet de pertànyer a la «nació» com el procés voluntari de construcció de trets comuns, com ara una llengua comuna, una cultura, una història, una experiència social i històrica i/o com un ideari social compartit (justícia, llibertat, democràcia, llibertat d'expressió, igualtat d'oportunitats, etc.). En el context del procés de secularització occidental, el darrer tipus de nacionalisme pot, de fet, ésser entès com una forma de "religió cívica» (Giner, 1993). Això és en bona part visible en els casos de Catalunya i el Quebec, tot i considerant encara el paper central de la religió catòlica fins fa ben pocs anys en aquests contextos. Els arguments a favor d'un nacionalisme «ètnic» — com ara la referència a la suposada 
existència d'una «raça pura»— són, en l'actualitat, difícilment defensables, no només després les lliçons apreses arran de l'experiment nazi, sinó també enfront de la realitat històrica d'hibridació (cultural i genètica) al llarg de la gran majoria d'anys de la història humana. Així doncs, el nacionalisme «cívic» o «cultural» és l'única marca que podria tenir alguna credencial positiva ara, malgrat el fet evident que les possibilitats de controlar les nostres pròpies identitats, tant individuals com col-lectives, són sempre d'alguna manera limitades. De fet, els dos nacionalismes, el natural i l'activista (o més aviat reflexiu, fruit de la llibertat i la consciència), no estan en contradicció, sinó que interactuen l'un amb l'altre. Accions conscients per tal de modificar el contingut de la representació nacional conclouen en un seguit de conseqüències intencionades $i$ (més sovint) no intencionades sobre la identitat col-lectiva que normalment són ben difícils de preveure. Tanmateix, això no significa que el nacionalisme "cívic» no es posi en dubte. De fet, el que constitueix el «nacionalisme cívic» és, en ell mateix, l'estat actual dels debats sobre quins haurien de ser els elements comuns. Per exemple, la preservació i promoció d'una llengua diferent és important (especialment a Catalunya i al Quebec). Una història comuna (com quelcom reconstruït i reinterpretat) són trets constitutius importants fins i tot pel nacionalisme cívic. I, tanmateix, les derrotes militars són marcadors simbòlics clau pel nacionalisme cívic, com la de 1759 al Quebec i la de 1714 a Catalunya. La composició política i el règim establerts després d'aquestes derrotes militars esdevenen també punts de referència centrals; per exemple: la Llei Constitucional de 1791 o la Llei de 1867 de l'Amèrica del Nord Britànica al Quebec i l'Estatut d'Autonomia de 1932 a Catalunya (Mancomunitat de Catalunya), que fou seguida pel règim centralista de Franco i més tard per l'Estatut d'Autonomia de 1979 i el restabliment de la Generalitat.

Per tant, un dels elements comuns en els nostres dos estudis de cas sembla que és el procés de construcció d'identitat «nacional» en relació amb, o més aviat en oposició amb, un «foraster» o, més aviat, amb un «altre»: «Espanya» o "Castella» per Catalunya i «la resta del Canadà» pel Quebec. Això és el que l'historiador del Quebec Jocelyn Létouneau caracteritza com el «soi-même et l'Autre» («un mateix i l'altre») (Létourneau, 1994: IX). Malgrat tot, aquesta relació amb l' "Altre vencedor» no significa que els nostres dos estudis de cas siguin o hagin esdevingut "colònies» desavantatjades o que caiguin necessàriament dins una classificació de "centre-periferia» (Brand, 1985). Per contra, Catalunya i el Quebec ja eren regions riques amb economies fortes en comparació amb altres regions, i contribuïren activament en la construcció de la nova entitat en la qual foren incloses. A part dels nacionalismes "ćivic» $\mathrm{i}$ «ètnic», hi ha un tercer tipus de nacionalisme normalment més prevalent en estats ben establerts. Com Michael Billing ha mostrat, molts països establerts (per exemple «estats» que no són substancialment posats en dubte des de dins) presenten també un fort nacionalisme, però un que pot ser anomenat «nacionalisme banal", un nacionalisme tan prevalent i donat per descomptat que ni es reconeix com a tal (Billing, 1995; Toogood i altres, 1999). Per exemple, als EUA es parla més de "patriotisme» que no pas de «nacionalisme» per se, encara que, 
al cap i a la fi, els seus efectes no siguin tan diferents (per exemple, quan es tracta de donar suport popular a les intervencions militars dels EUA).

\section{Reificació dos: natures}

Allò que ara es considera "natura» dins d'un context nacional és també fruit d'un procés de reificació i hibridació. Per exemple, tant en el cas de Catalunya com en el del Quebec, les «muntanyes» - els Pirineus i altres muntanyes interiors a Catalunya i la vasta serralada boscosa de les Laurentides al Quebecsembla que són un dels objectes naturals clau que ressonen dins de la identitat nacional. I, a la vegada, les ciències naturals - els missatges de les quals foren després reinterpretats pels ecologistes - desenvoluparen un paper central en la definició del que ara entenem com a «muntanya».

Òbviament, aquest no és un fenomen exclusiu de les nostres localitzacions triades en aquesta investigació. Per exemple, en el cas de Canadà, Suzanne Zeller (1987) ha il.lustrat clarament que l'emergència d'objectes específics — com ara "roques» $\mathrm{i}$ "boscos»— mitjançant les ciències naturals com ara la geologia i la cartografia, foren el resultat de configuracions «canadenques» específiques. En aquest sentit, fou l'Exèrcit britànic a la dècada de 1840 qui començà a realitzar sistemàticament esbossos dels primers mapes i estudis geològics del Canadà. Hi havia, naturalment, raons d'estratègia militar en l'anomenament dels noms de lloc, com fou la consolidació d'un domini britànic a l'Amèrica del Nord des de la costa est fins a la de l'oest, enfront de la persistent amenaça d'una invasió dels Estats Units (com ocorregué el 1812) i altres raons «internes» d'amenaces, tot i que cada cop eren menys importants per part dels nadius i mestissos. Aquests mapes i estudis geològics del Canadà serien més tard la base d'extraccions minerals i la construcció de la xarxa de ferrocarrils transcontinentals. Aquests factors - tot i que eren acurats-, això no obstant, no expliquen, però, en justa mesura el perquè de l'emergència d' «objectes naturals» específics al Canadà. Aquesta coconstrucció natural i nacional fou també fruit de la contingència i les dificultats de construir una identitat pancanadenca a la vista de l'absència d'un sol tret, obvi, compartit, homogeni i dominant, com podria ser l'«etnicitat» (atesa la diversitat entre les societats nadiues, i dels europeus nouvinguts, que incloïen anglesos, escocesos, irlandesos, francesos i immigrants asiàtics), la "religió» (una majoria de catòlics a finals del segle XVIII; en l'actualitat hi ha més o menys el mateix nombre de catòlics que de protestants, però cal afegir-hi un nombre important de practicants d'altres religions i també de seculars), la «llengua» (tot i que l'anglès és en l'actualitat la dominant, una quarta part dels canadencs són francòfons), o la identitat «geogràfica» (moltes diferències geogràfiques a través de tot el continent). En el cas d'Espanya, hi tingué lloc un procés similar (Gómez Mendoza i altres, 1992). Per exemple, Eric Swyngedoun (1999) ha mostrat molt bé com la recerca i les polítiques hidrològiques foren factors importants en la construcció de l'Estat espanyol i de la identitat espanyola. Prou interessant, en aquest aspecte, és la divisió administrativa de Catalunya, basada en "comarques», que intentava adaptar i seguir 
l'orografia i el paisatge «naturals» del Principat. Les comarques foren sovint utilitzades com un símbol polític en contra de les fronteres establertes per l'Administració espanyola, basades en "províncies» i que no tingueren en compte les característiques geogràfiques.

L'existència d'objectes naturals i nacionals a Catalunya i al Quebec no és, llavors, tan sorprenent. La construcció de categories "naturals», com ara muntanyes, com a representacions col-lectives nacionals i naturals fou, en gran mesura, l'efecte híbrid de les ciències naturals amb la representació de "fets físics», així com d'altres processos "històrics», com fou la construcció d'estat -o la manca aquest estat—, tant al Quebec com a Catalunya. En aquest context, ja podem remarcar que, en aquestes nacions sense estat, hi haurien tingut lloc efectes híbrids similars per tal de contrarestar els que emergien de contexts polítics i geogràfics més grans (per exemple, Espanya i el Canadà respectivament). Per exemple, a Catalunya, les muntanyes esdevingueren, al segle XX, un refugi religiós, lingüístic i nacional (i especialment recollit pel moviment excursionista) contra la dictadura de Franco, mentre que, al Canadà, les muntanyes Laurentides i els seus boscos esdevingueren una de les representacions més simbòliques de la llibertat dels coureurs de bois i, subsegüentment, un símbol de la identitat francòfona del Quebec. Així, no és pas per accident que un banc (centrat al Quebec) s'anomeni Banque Laurentienne i que una de les cerveses Molson s'anomeni «laurentide» mentre fora del Quebec s'anomeni «canadenca». Avui en dia, tots dos llocs són també destinacions turístiques prou populars.

A més a més, tots dos moviments, el nacionalista i l'ecologista, s'han anat intensificant $\mathrm{i}$, en certa mesura, acabaren convergint en molts aspectes, $\mathrm{i}$ originàriament fruit del romanticisme (F. Walter, 1990), en un moment en el qual les societats modernes estaven cercant referències no destruïdes de la puresa natural i l'ordre social col.lectiu (per exemple, mitjançant un procés de reificació). Com a conseqüència de la industrialització, indrets que poguessin representar l'harmonia entre els humans i el món no humà eren cada cop més escassos, i, així, la natura i la nació foren substituïdes per aquest desig d'harmonia. Si algú pogués trobar un lloc on la natura i la nació esdevinguessin un, aquest seria el lloc on els orígens purs de la comunitat nacional es trobarien i transcendirien el futur. La relació entre el moviment ecologista i el moviment nacionalista ha estat estudiada per Barcena i altres (1997), qui mostren aquestes relacions també per al cas de les nacions sense estat del País Basc i Estònia (si bé aquesta última va assolir al seva independència el 1991).

Llocs reificats com ara les muntanyes no només existeixen en el domini de la cultura o en el domini de la natura en formes pures. Existeixen en una zona d'intersecció entre la cultura i la natura, on la majoria de les identitats nacionals fan regulars les seves pròpies referències i les recreen. Aquests llocs han resistit al projecte modern de separació de la natura de la cultura i de localització de la societat humana en una posició particular (normalment superior). També han resistit a la creació de totalitats inqüestionables entre estats nació dominants. Un cop trobats i identificats, aquests llocs ja no poden ser total- 
ment purificats en objectes naturals o en objectes nacionals. De fet, s'obren a uns altres significats i a unes altres pràctiques subjacents que tenen poc a veure solament amb la nació o solament amb la natura, tal com veurem a continuació amb més detall.

\section{Hibridació a les Laurentides: el coureur de bois del Quebec}

Les Laurentides són un espai configurat per un seguit de petits turons (amb una mitjana d'alçada de 240 metres) que formen una plana — que conté milers de llacs - situada al nord de la conca del riu Sant Llorenç a la província del Quebec i d'una llargada de centenars de quilòmetres. Hi ha, a més a més, un parc natural amb el mateix nom situat al nord de la ciutat del Quebec. Com veurem, les Laurentides (Laurentians en anglès) estan fortament lligades amb la identitat quebequesa. Tanmateix, la identitat nacional del Quebec és el resultat d'una reinterpretació relativament recent mitjançant el que es coneix com la «Revolució Silenciosa», fruit de la tria, el 1960, d'un govern liberal quebequès compromès amb la secularització, la intervenció estatal i la modernització econòmica. Al Quebec, l'any 1960 simbolitza un canvi del catolicisme, de les tradicions, de la ruralitat i de la percepció de ser francescanadenc («canadiens») cap al secularisme, cap allò modern, cap a la urbanitat i la nova percepció de ser «quebequès». Òbviament, hi ha superposicions que persisteixen entre les identitats "canadenca» $\mathrm{i}$ "quebequesa», fruit en part d'experiències compartides a través de totes les regions canadenques, com pot ser la duresa i la durada dels hiverns (Lamontagne, 1983).

En el seu tan remarcable Thematic Guide to Canadian Literature, de 1972, Margaret Atwood caracteritzava el tema literari central i més important pels immigrants europeus com la "supervivència» en el context de llargs i durs hiverns, enmig d'animals i espècies de plantes desconegudes, i la sovint densa, vasta $\mathrm{i}$ impenetrable vegetació que requerien mitjans de transport poc familiars (per exemple: piragüisme, traginar). Molts dels primers nous colons sobrevisqueren exclusivament mercès a l'ajut i el coneixement adquirit de les poblacions indígenes més familiaritzades amb l'entorn «natural». Els colons europeus aprengueren ràpidament a sobreviure mitjançant l'agricultura de supervivència, però també comerciant amb les enormes i riques quantitats d'elements «naturals», com ara la pell, en un primer moment, o la fusta i els minerals, més tard.

Quan el rei francès perdé la majoria de les seves possessions colonials a l'Amèrica del Nord (1760) en favor dels britànics, una estimació del 90\% de la població europea establerta al que ara és Ontario, el Quebec i les províncies marítimes era francesa. Per tal d'assegurar la lleialtat dels colons francesos a la Corona britànica, algunes de les poblacions de la costa est (els Arcadians) foren deportades i escampades pel continent, mentre que a d'altres regions francòfones se'ls atorgà un estatus constitucional relativament generós en termes de llibertat religiosa (catolicisme), dret a l'educació en francès i certa autonomia política, que fou establerta amb la Llei de l'Amèrica del Nord Britànica, de 1867, 
la qual encara conforma l'espina dorsal de la constitució actual del Canadà. Malgrat molts intents repetits per part de la Corona britànica — durant gran part del segle XIX — de reduir (per tal d' «assimilar») la població francesa, els francòfons se les manegaren per preservar llur llenguatge i llur cultura. Un dels estranys espais de "resistència» fou precisament a través de la "natura» $i$, en gran mesura, a les Laurentides.

De fet, una de les característiques clau de la identitat del Quebec sorgí mitjançant la pràctica del coureur de bois, que consisteix en la migració i el nomadisme estacional de molts homes del Quebec (als segles XVIII i XIX, principalment cap a les profunditats dels boscos, per tal de caçar animals per aconseguir-ne les pells i/o per comerciar amb pell amb els nadius). Això significava que, mentre els homes eren fora durant uns quants mesos, les dones realitzaven les activitats més sedentàries, com ara tenir cura dels infants, l'educació i l'agricultura. Les activitats del coureur de bois proporcionava un ingrés complementari substancial per a l'agricultura de subsistència de molts quebequesos (o, més aviat, "canadiens», com se'ls anomenava aleshores). Més enllà dels avantatges econòmics de les activitats del coureur de bois, hi havia també uns altres aspectes menys visibles, com és el cas de l'establiment d'una segona família amb una dona nadiua, en part com una manera d'assegurar un accés privilegiat a la pell i a l'ajut per part dels nadius. La vida nòmada del coureur de bois permetia també escapolir-se de la mirada de l'autoritat colonial (britanicoanglesa) i de l'Església catòlica (francòfona). La construcció del silenci al voltant de la vida de fet del coureur de bois fou també com a conseqüència que aquells qui tenien el temps o les capacitats per escriure sobre el coureur de bois eren aquells qui no estaven efectivament compromesos amb les seves activitats. Aquells qui escrigueren sobre la vida efectiva del coureur de bois eren, o bé part de l'elit masculina educada (principalment procedents de l'Església catòlica) que temien (i/o envejaven!) la probabilitat d'èxit de molts coureurs de bois de convertir-se en "nadius» amb els pobles indígenes, i de perjudicar així l'estratègia per la supervivència francòfona, en tenir unes altes taxes de natalitat («la revenja del bressol»), o bé dones europees literates. En el context de la derrota militar de 1759 (i el retorn de la noblesa francesa a França), el que restà de l'elit del Quebec esdevingué una desesperada imatge de models (masculins) de comportament que pogueren esdevenir símbols per a la supervivència de la identitat col-lectiva. En molts casos, la història del coureur de bois fou escrita per dones (literates europees). Encara avui en dia, moltes de les representacions de la cultura popular dels segles XVIII i XIX del Quebec se centren al voltant de la freqüent absència de «mascles» (per exemple: una sèrie de televisió extremament popular de l'any 1986, anomenada Les filles de Caleb, il.lustrava molt bé tots aquest aspectes; per a una discussió mes completa, consulteu Marshall, 2000). L'acció mateixa d'escriure sovint també esdevenia un mitjà per generar ingressos addicionals per a la família, al mateix temps que permetia abordar les angoixes sobre què devien fer exactament els membres masculins a la muntanya. Tanmateix, és l' «absència» masculina mateixa el que generà la seva «sobrepresència» en els discursos, a la vegada que construí social- 
ment el coureur de bois com un símbol — tot i que certament ambigu-dels francocanadencs i, més tard, de la identitat nacional del Quebec. Per exemple, les activitats del coureur de bois eren vistes com a pràctiques de la llibertat: una llibertat econòmica a través del guany d'ingressos addicionals mitjançant l'ús de tota mena de recursos naturals com ara la pell dels animals, i llibertat "masculina» respecte a la rigidesa de la vida familiar monògama, del sedentarisme de dur la granja, del catolicisme, bo i creant, doncs, simultàniament, una cultura de nomadisme masculí i de matriarcat sedentari (Ouellet i altres, 1997: 76-81; Nadeau, 2001).

Si bé el coureur de bois fou fonamentalment un fenomen dels segles XVIII i XIX, continua influenciant les pràctiques socials d'avui en dia al Quebec. Per exemple, molts quebequesos gaudeixen en especial de fer activitats a l'aire lliure, com ara piragüisme, excursionisme, esquí, caça i pesca en els mateixos llocs i de maneres que, en gran mesura, recorden l'estil de vida dels coureurs de bois. De fet, anar de cap de setmana o de vacances a una cabana normalment a la vora d'un llac a les Laurentides per recrear les experiències d'aquest imaginari col-lectiu continua essent una activitat molt apreciada i desitjable. És, doncs, difícil classificar aquestes activitats humanes actuals com a, simplement, «esbarjos», «explotacions» o «apreciacions» de la natura. No és ni una cosa ni l'altra. Hi ha també pràctiques actives de construcció d'identitats col-lectives i individuals. Les representacions actuals del Quebec — com ara les pel-lículesestan completament plenes de referències obligatòries a passatges durant els quals els protagonistes - que viuen generalment en una ciutat - es troben fent piragüisme, anant de pesca o de caça recreant el modus vivendi dels coureus de bois. Més concretament, els personatges masculins tendeixen a renovar o a descobrir les seves relacions amb el seu "pare» - qui havia estat fora fins aleshores-, tot duent a terme alguna de les activitats masculines com ara la caça o la pesca. Per exemple, a la pel-lícula de Denis Lauzon Un zoo la nuit, el protagonista, que té una relació ambigua i complicada amb el seu pare, fa les paus amb ell (frontera intergeneracional) durant i després d'una catàrtica expedició de caça a un zoo que es converteix en un succedani híbrid i modern del bosc.

Hauria de quedar clar que els discursos sobre «protegir»o «conviure» amb el medi ambient generen un soroll ambigu al Quebec, i aquest és fruit del significat profund de pràctiques antigues al voltant de l'explotació comercial de la natura, com fou l'economia política del coureur de bois, estretament lligada amb la identitat del Quebec. La intensificació actual de l'explotació dels recursos naturals (silvicultura, electricitat hidroelèctrica i mineria), simultàniament, manté la identitat del Quebec i amenaça la seva supervivència. És per aquest motiu que moltes de les activitats a l'aire lliure dels urbanites del Quebec poden ser considerades com a activitats dels «coureurs de bois contemporanis» (Pilon, 1985). I, tanmateix, la desaparició actual dels boscos del Quebec com a conseqüència de la gran extracció de fusta assenyala també la desaparició de l'espai del qual sorgí la identitat nacional del Quebec. 


\section{Hibridació a les muntanyes: Montserrat i Catalunya}

Com hem vist en el cas del Quebec, els llocs muntanyencs han tingut i continuen tenint un paper important en la construcció de la identitat nacional. En el cas de Catalunya, com s'anomena habitualment una nació sense estat del nord-est d'Espanya i del sud-est de França, les muntanyes han tingut també una gran significació ja des dels seus mateixos orígens com a comtat independent de França l'any 898 (la «Marca Catalana»). Amb els Pirineus al nord i moltes altres serralades al llarg de la costa mediterrània, Catalunya és una de les regions més muntanyenques de tot Europa i, sens dubte, això ha imbuït la seva gent d'una idiosincràsia especial. Jaume Vicens Vives, un dels historiadors catalans més coneguts, en una interpretació d'alguna manera ecoromàntica i nacionalista, assenyala que és precisament a les muntanyes on sorgeixen les característiques més distintives de la cultura catalana. Segons ell:

A la muntanya s'ha creat el nervi de la mentalitat catalana. No oblidem que fins al segle XIII la muntanya guardà les reserves humanes i espirituals del país i que els creadors de la nostra personalitat històrica foren homes muntanyencs [...]. Durant tres segles, s'hi formà el millor de què podem lloar-nos actualment: l'esperit feiner, el seny, el sentit de la continuïtat, la tradició familiar i la responsabilitat social. (1995, p. 28-29)

A Catalunya en particular, hi ha hagut força lligams en la reverència a les muntanyes i en la conservació forestal. Així, la «festa de l'arbre» ja va ésser oficialment instaurada a Catalunya el 23 de març de 1899, per part de l'enginyer agrícola Rafael Puig i Valls. Tal com destaquen López-Vázquez i BrugueraNadal (2000: 27, 79), seria el mateix Rafael Puig i Valls qui acabà per redactar i editar, l'any 1902, un estudi que hauria de ser cabdal en la història de la conservació a Catalunya: el Proyecto de Parque Nacional de la Montaña de Montserrat, que hauria de ser la primera proposta i el primer intent seriós d'establir un espai en règim de preservació a l'Estat espanyol, malgrat que posteriorment no va reeixir (el primer parc nacional a Espanya fou creat el 1914 a Covadonga, a la serralada Cantàbrica, lloc també enigmàtic en la representació d'Espanya com a estat nació, ja que simbolitza l'origen de la reconquesta cristiana mitjançant la figura de Don Pelayo).

Així doncs, veiem que entre les nombroses serralades de Catalunya, Montserrat constitueix no solament un dels símbols més importants de la seva identitat nacional, sinó també un dels símbols més importants de la història de la conservació natural. El seu monestir principal conté una imatge romànica del segle XII que representa la Mare de Déu de Montserrat, la moreneta i patrona de Catalunya. Sota el règim franquista, el monestir de Montserrat esdevingué un dels estranys llocs on la llengua i la cultura catalanes podien, públicament i simbòlicament, ser utilitzades en un entorn relativament segur. En aquest sentit, el monestir d'aquesta «muntanya sagrada» — com hom s'hi refereix habitualment - desenvolupà el paper de conservador lingüístic i cultural, com també ho feu l'Església catòlica al Quebec. A Catalunya, essent com 
és un país petit (més o menys de la mida d'Holanda), les muntanyes de Montserrat emergeixen de les planes relativament baixes de l'interior com una fita central, la qual pot ser vista tant des dels Pirineus al nord, com des de les terres muntanyenques de Tarragona al sud. En comparació amb les Laurentides, Montserrat és minúscula, ja que cobreix només 3.630 hectàrees (i una zona periferica addicional de protecció de 4.039 hectàrees) i difícilment podria ser considerada un espai «veritablement verge». L'any 1986, un gran incendi devastà una extensa àrea de la muntanya, que en delmà més de la meitat de la coberta forestal. A més a més, cap a mitjan anys noranta, Montserrat rebia més de 2,3 milions de visitants anualment, amb la qual cosa esdevingué el segon lloc més visitat de Catalunya després de Barcelona (Massot, 1972; Molas i Rifa, 1998). Tanmateix, tot això no ha fet minvar la possibilitat que tant els turistes com els autòctons visquin una mena d'experiència ecoreligiosa i/o catalanista quan visiten Montserrat. Són les pedres, i no pas la natura viva, les que corprenen els visitants, tal com podria haver succeït en els temps prehistòrics, quan formacions rocoses particulars s'utilitzaven per objectius religiosos. Pels visitants actuals, Montserrat té tots els atributs per ser un perfecte lloc de conversió nacionalista i ecoreligiosa (Giner i Tàbara, 1998).

Malgrat la facilitat més gran d'accés a Montserrat, com a conseqüència de l'existència als voltants d'una extensa xarxa de transport (trens i carreteres), mitjançant funiculars o el tren cremallera, aquest fet no ha impedit que constituís una atracció com a mite ecològic i nacional. Ans al contrari, tot això ha generat noves oportunitats per a un nou reencantament natural i religiós i per a una nova reidentificació nacionalista. Ja hi ha a l'abast nombroses pàgines d'Internet que novament declaren la importància de Montserrat com a monument naturalnacional i que proporcionen informació detallada de caminades guiades per poder aconsellar els visitants sobre com poden participar en aquesta experiència ecoreligiosa i nacionalista única. Com un dels intel.lectuals locals expressà mentre reflexionava sobre el significat actual de Montserrat i el seu futur al tombant de mil.lenni:

Montserrat s'equipara amb Catalunya, de la qual és símbol [...]. El poble que veu aquesta serralada de silueta inhabitual s'identifica amb ella; ella, una part del país, representa el conjunt [...]. Si Catalunya és cada vegada més petita, Montserrat pot esdevenir cada cop un símbol més universal. (Ribera Mariné, 1998, p. 111-112)

Montserrat representa la permanència i la continuïtat en el temps, una fita natural preciosa de l'imaginari català que s'estén al passat i es projecta al futur. Més que un objecte cultural o construït per l'home, els catalans han triat Montserrat com el símbol cultural d'identitat nacional que representa, a la vegada, una raresa geomorfològica i una «benedicció de Déu». D’una manera semblant a com Josep Llobera troba els carrers del districte modernista de la Barcelona de l'Eixample un dels llocs on els catalans localitzen, redescobreixen i rememoren la seva «memòria històrica» («modernista») (Llobera, 1996), 
Montserrat sembla que acompleix també aquesta funció d'enaltir, recrear i projectar la consciència i la memòria col-lectives — tot i que de manera diferent, bo i establint una «referència natural» i d'identitat catalana en el temps i en l'espai.

Sens dubte que la globalització i el turisme de masses transformaran aquest símbol «universal» que constitueix l'híbrid Montserrat-Catalunya (naturanació) en mars encara inexplorades. Tan aviat com Montserrat sigui engolida per la cultura global (Urry, 1995), el seu contingut simbòlic i cultural no serà mai més modelat exclusivament ni pels catalans ni pels capellans, ni tampoc pels científics naturals. Els seus significats seran certament transformats $\mathrm{i}$ «transportats» pels nouvinguts, autòctons o no, així com els comunicadors globals. Tots junts rememoraran antigues experiències i en crearan de noves. Però, segurament, la nova Montserrat, ja reconeguda com un híbrid entre religió i ciència, entre modernitat i tradició, entre la cultura oral i els mitjans de comunicació globals, i entre les introspeccions espirituals i l'entreteniment global, continuarà explicant realitats noves i profundes del passat, del present i del futur dels catalans, dels visitants, així com el nostre lloc en aquest ordre còsmic que inevitablement configura entremig de la cultura i la natura.

\section{Conclusió}

En aquest article no defensem que les «muntanyes» expliquin necessàriament l'existència de nacionalisme en els dos contextos socials considerats. Tampoc no tractàvem d'argumentar-hi que el nacionalisme necessita les muntanyes a fi d'afirmar la seva existència ontològica. Més aviat, el nostre objectiu se centra en l'observació evident que aquestes nacions sense estat han estat particularment propenses a explicar l'origen de les seves peculiaritats culturals i les localitzacions de l'expressió sublim de les seves idiosincràsies en indrets remots i relativament inaccessibles, lluny dels poders —estatals o mundials- dominants; que aquests processos són insuficientment explicats per consideracions únicament biofísiques o socialconstructivistes, i que fenòmens històrics i geogràfics com aquests es poden entendre millor amb l'ajut de categories heurístiques que fan referència als processos d'hibridació i reificació d'objectes que es troben en un punt de contacte entre «natura» $\mathrm{i}$ "cultura». Els nostres dos estudis semblen suggerir que podria ser particularment enriquidor dur a terme uns altres estudis comparatius específics des d'una perspectiva com aquesta a d'altres llocs o cultures que podrien presentar «objectes naturals» similars. Aquest és el cas, per exemple, d'altres espais on la cultura nacional es refugia i es recrea en la natura, generant una unitat indivisible i mútuament necessària en l'explicació de totes dues, com són les muntanyes de l'Aragac a Armènia i de l'Himàlaia al Tibet, els turons a la cultura jueva, els Highlands a Escòcia, o fins i tot els manglars a l'Equador i a l'est de l'Índia, o els aiguamolls a l'Iraq o a Louisiana.

En els dos estudis de cas nostres - més a Catalunya que al Quebec, tanmateix-, hi ha un nombre d'elements que eviten que l' «objecte natural» sigui definit exclusivament com a «recurs natural» $i$, doncs, des d'una perspectiva 
únicament econòmica o utilitarista. Això, a la pràctica, actua com un preventiu per a la seva destrucció, en evitar que aitals referents naturals i culturals siguin «desencantats». I, paral.lelament, en gran mesura, un factor important - tot i que no l'únic — per garantir la «supervivència» del concepte de "nació» és el grau en què la seva "naturalesa» roman «encantada» $\mathrm{i}$ "reencantada», ja sigui a través de la cultura popular, les creences religioses, els discursos científics o, d'una manera menys important, dels mitjans de comunicació de massa i el turisme. Així, si la identitat cultural només pot ser desenvolupada i conservada mentre es manté un lligam col-lectiu amb tot un seguit de fites espacials singulars, ens sembla molt clar, doncs, que fites d'aquesta mena hagin de gaudir d'un alt grau de "puresa natural». A més a més, normalment, han de representar llocs on aquesta puresa natural és «segura». En aquestes localitzacions, els components essencials de la identitat nacional han de defensar-se de ser engolits per la globalització, la banalització i la desespacialització contemporànies, ja que poden i han de ser protegits per la cultura local en contínua evolució i per la seva gent, els únics capaços d'experimentar el misteri i la revelació econacional. Amb tot, però, el fet que una serralada romangui simbòlicament unida a una identitat nacional, no en garanteix necessàriament la preservació ambiental. Per contra, pot accelerar la seva destrucció efectiva, com és el cas de Montserrat, amb l'impacte del turisme de masses, o de les Laurentides, amb la construcció de xalets al voltant de la riba de molts llacs, la utilització de motos de neu o la talla intensiva d'arbres. De fet, com hem vist en aquest article, la identitat nacional del Quebec ha estat en gran mesura sostinguda per l'explotació sistemàtica i la comercialització dels recursos naturals. Per altra banda, podria ser precisament mitjançant el turisme de masses i les activitats de lleure a l'aire lliure que aquests objectes «naturals» siguin novament redefinits simbòlicament d'una manera molt poderosa, però aquest cop podria ser que no com a icones "nacionals».

Finalment, podem també concloure que el concepte teòric de Latour d'hibridació ens permet examinar d'una manera crítica categories determinades, explorar la seva construcció històrica, revelar alguns dels seus embolics, de les seves inestabilitats o de la seva durabilitat. El concepte de Latour ens proporciona l'eina per evitar de prendre cap categoria conceptual de manera massa seriosa (per exemple, si parlem des d'un punt de vista ontològic), mentre que, al mateix temps, les podem continuar fent servir discursivament i creativa en absència d'un llenguatge neutre o una posició «des de fora» (des d'un punt de vista epistemològic). En fer servir l'enfocament de Latour en els nostres casos, les nostres observacions revelen les dificultats — si no la impossibilitat- de parlar d'objectes híbrids fora de l'existència de categories epistemològiques reificades. Una solució seria la de constituir la «hibridació» com una categoria reificada en ella mateixa (i, per tant, epistemològicament no funcionaria). O bé, hauríem d'acceptar la debilitat del projecte modern de definició del món en categories estàtiques i excloents i viure amb l'ús constant de cometes al voltant dels termes específics, per tal d'aclarir que aquests no volen dir el que normalment volen dir, amb la qual cosa indicaríem la impossibilitat de donar-los 
un nom. Òbviament, hi ha seriosos problemes potencials epistemològics amb l'estratègia latouriana. Per exemple, com és possible que els humans de reconeguin els no humans d'una manera que no sigui antropocèntrica o determinista en l'anàlisi final? Poden els humans reconèixer del tot els no humans en els seus propis termes? És possible de distingir els elements humans i no humans en un híbrid latourià? Si això és possible, el lector és conduït novament cap a la divisió entre humans i no humans. Si això no és possible, quina és la naturalesa epistemologicometafísica de l' «autor», i dels texts sobre els "híbrids»? I, encara més important: com és possible reconèixer els "híbrids» en els seus propis termes? Què significa "en els seus propis termes»? Totes aquestes qüestions han estat al cor de la nostra recerca. Els avenços futurs, tant pels geògrafs culturals com pels sociòlegs ambientals, dependran de la mesura en què aquests reptes estiguin també en el centre de les seves agendes de recerca. Enfrontat amb les crítiques, principalment de caràcter epistemològic, dels seus treballs inicials, Latour ha intentat més recentment (Latour, 2004, 2005) aportar unes propostes més concretes sobre què podria arribar a ser una "política de la hibridació» que reconegués tant els actors humans com no humans i fer veure com podrien arribar a ésser aquests nous «actants». Tot i fer això, Latour està arribant a donar elements que ens permeten trobar resposta a les preguntes plantejades en aquest article. De fet, Latour ha mogut ja la problematització que implica la seva contribució del pla epistemològic al polític. Si volguéssim llavors avaluar les preocupacions més recents de Latour, una possibilitat de futures investigacions podria consistir a reprendre aquesta anàlisi comparativa a partir dels esdeveniments també més recents ocorreguts tant en la construcció del nacionalisme contemporani com en la construcció de la "natura» en tots dos processos. A Catalunya, per exemple, aquest cas ha estat especialment paradigmàtic en la creació del Pla d'Espais d'Interés Natural, el pla més ambiciós de conservació de la natura mai promogut al Principat i que ha estat també estretament lligat a la consolidació de les seves institucions nacionals al llarg de les darreres dues dècades. Amb tot, però, deixarem aquesta nova hipòtesi sobre la demostració de les polítiques contemporànies de la hibridació de Latour a Catalunya i el Québec, per a la nostra futura recerca.

\section{Bibliografia}

ATwood, M. (1972). Survival: A Thematic Guide to Canadian Literature. Toronto: Anansi.

Balcells, A. (1996). Catalan Nationalism: Past and Present. A: Walker, Geoffrey J. (ed.). Nova York: St. Martin's Press.

Barcena, I.; Ibarra, P.; Zubiaga, M. (1997). The Evolution of the Relatiohship between ecologism and nationalism. A: REDCLIFT, M.; WoOdGATE, G. The International Handbook of Environmental Sociology. Cheltheham: Edward Elgar.

BILLIG, M. (1995). Banal Nationalism. Londres: Sage.

BRAND, J.A. (1985). «Nationalism and the Noncolonial Periphery: A Discussion of Scotland and Catalonia». A: TiRYANKIAN, Edward A.; RoGOwsKI, Ronald (eds.). New Nationalisms of the Developed West. Boston: Alen \& Unwin. 
BRETON, R. (1996). «From Ethnic to Civic Nationalism: English Canada and Quebec». A: Hutchinson, John; Smith, Anthony D. (eds.). Ethnicity. Nova York: Oxford University Press.

CLIFT, D. (1987). Le pays insoupçonné: Essai. Quebec: Libre Expression.

Coleman, W.D. (1984). The Independence Movement in Quebec, 1945-1980. Toronto: University of Toronto Press.

DANIELS, S. (1993). Fields of Vision: Landscape Imagery and National Identity in England and the United States. Cambridge: Polity Press.

DARIER, E. (1995). «Premises about Environmental Studies: Knowledge, Language, History and the Self». A: MeHTA, Michael D.; Ouellet, Eric (eds.). Environmental Sociology: Theory and Practice. Toronto: Captus Press.

DARIER, E. (ed.) (1999). Discourses of the Environment. Oxford: Blackwell.

- (2005). «Foucault and the Environment: an Introduction». A: REDCLIFT, Michael R.; Woodgate, Graham (eds.). New Developments in Environmental Sociology. Cheltenham, UK: Edward Elgar Publishing.

RiQuer, B. de (1990). "Le nationalisme catalan de 1960 à 1986». A: TREMBLAY, Gaëtan; PARĖS I MAICAS, Manuel (eds.). Autonomie et mondialisation: Le Québec et la Catalogne à l'heure du libre-échange et de la Communauté Européenne. Sillery: Presses de l'Université du Québec: 7-28.

Demeritt, D. (1995). "The Wild Life and the Re-Creation of Man: Nature, Masculinity, and the Experience of the Maine Woods». Article presentat a la trobada de l'Association of American Geographers, 14-18 de març de 1995, Chicago.

- (2002). What is the "social construction of nature»? A typology and sympathetic critique. Progress in Human Geography, 26, 766-789.

Díez Medrano, J. (1995). Divided Nations: Class, Politics and Nationalism in the Basque Country and Catalonia. Ithaca: Cornell University Press.

Gagnon, A.-G.; Montcalm, M. B. (1990). Quebec: Beyond the Quiet Revolution. Scarborough, Ontario: Nelson Canada.

Gagnon, A.-G.; Tully, J. (2001). Multinational Democracies. Cambridge: Cambridge University Press.

Gagnon, A.-G.; Guibernau, M.; Rocher, F. (2003). The Conditions of Diversity in Multinational Democracies. Montréal: IRPP/McGill-Queen's University Press.

FreundenburG, W. R.; Frickel, S.; Gramling, R. (1995). «Beyond the Nature/Society Divide: Learning to Think like a Mountain». Sociological Forum, vol. 10(3): 361-92. Giner, S. (1980). The Social Structure of Catalonia. Sheffield: The Anglo-Catalan Society / University of Sheffield Printing Unit.

- (1993). «Religión civil». Revista Española de Investigaciones Sociológicas, vol. 61: 23-55.

GINER, S.; TÀBARA, D. (1999). "Cosmic Piety and Ecological Rationality». International Sociology, vol. 14 (març): 59-82.

Gómez Mendoza, J.; OrTega Cantero, N. (eds.) (1992). Nacionalismo y geografía en España. Madrid: Fundación Banes Exterior.

Guibernau, M. (1996). Nationalisms: The Nation-State and Nationalism in the Twentieth Century. Cambridge: Polity Press.

- (1997). "Nations without States: Catalonia, a Case Study». A: Guibernau, Montserrat; ReX, John (eds.) (1997). The Ethnicity Reader: Nationalism, Multiculturalism and Migration. Cambridge: Polity Press: 133-54.

- (1999). Nations Without States (translations: Catalan and Chinese). Cambridge: Polity Press. 
- (2004). Catalan Nationalism: Francoism, Transition and Democracy. Londres: Routledge.

Guibernau, M.; ReX, J. (eds.) (1997). The Ethnicity Reader: Nationalism, Multiculturalism and Migration. Cambridge: Polity Press.

HaraWay, D. J. (1991). Simians, Cyborgs and Women: The Reinvention of Nature. Londres: Free Association Books.

Keating, M. (1996). Nations against the State: The New Politics of Nationalism in Quebec, Catalonia and Scotland. Londres: MacMillan Press Ltd.

Keating, M. (2001). Plurinational Democracy. Stateless Nations in a Post-Sovereignty Era. Oxford: University Press.

LAMONTAGNE, S. (1983). L'hiver dans la culture Québécoise (XVIIe-XIXe siècles). Québec: Institut québécois de recherche sur la culture.

Latour, B. (1993). We Have Never Been Modern. Cambridge: Harvard University Press.

- (2004). Politics of Nature: How to Bring the Sciences into Democracy. Cambridge, Mass.: Harvard University Press.

- (2005). Reassembling the Social: An Introduction to Actor-Network-Theory. Oxford University Press.

LÉTOURNEAU, J. (ed.) (1994). La question identitaire au Canada francophone: Récits, parcours, enjeux, hors-lieux. Sainte Foy: Les Presses de l'Université Laval.

- (2004a). Le Québec, les Québécois. Un parcours historique. Montréal/Fides, Québec: Musée de la civilisation.

- (2004b). A History for the Future: Rewriting Memory and Identity in Quebec. Montréal/Kingston: McGill-Queen's University Press.

Levine, M. V. (1997). "Canada and the Challenge of the Quebec Independence Movement». A: VAN HORNE, Winston A. (ed.). Global Convulsions: Race, Ethnicity, and Nationalism at the End of the $20^{\text {th }}$ Century. Albany / Estat de Nova York: SUNY Press: 315-338.

López I VÁzQuez, X.; BRugera i NADAL, N. (coords.). La festa de l'arbre. Un fet català de projecció Europea (1899-1999). Girona: Diputació de Girona.

LlOBERA, J.R. (1989). «Catalan National Identity: The Dialectics of Past and Present». A: TonkIn, Elizabeth; MCDOnald, Maryon; Chapman, Malcolm (eds.). History and Ethnicity. Londres: Routledge: 247-61.

- (1994). The God of Modernity: The Development of Nationalism in Western Europe. Oxford: Berg Publishers.

- (1996). The Role of Historical Memory in (ethno) Nation-builiding. Londres: Goldsmiths College, University of London corp.

MACNAGHTEN, J.; URRY, J. (1995). «Towards a Sociology of Nature». Sociology, 29(2): 203-220.

Marshall, B. (2000). Quebec National Cinema. Montreal: McGill-Queen's Press. Massot, J. (1972). Història de Montserrat. Barcelona: Publicacions de l'Abadia de Montserrat.

MCrOBerTs, K. (1988). Quebec: Social Change and Political Crisis. Toronto: McClelland and Stewart.

- (2002). Catalunya: Una nació sense estat. Barcelona: Proa-literària.

MichaEl, Mike (1996). Constructing Identities: The Social, the Non-human and Change. Londres: Sage.

MOLAS I RIFÀ. J. (1998). «Els serveis d'acolliment de Montserrat davant els nous reptes de la societat». A: ABADIA DE MONTSERRAT, Montserrat al Llindar del Tercer Mil.lenni. Barcelona: Publicacions de l'Abadia de Montserrat, p. 35-76. 
NAdeAu, C. (2001). Fur Nation: From The Beaver to Brigitte Bardot. Londres: Routledge. Ouellet, Real; Beaulieu, Alain; Tremblay, Mylène (1997). «Identité québécoise, permanence et évolution». A: TURGEON, Laurier; LÉTOURNEAU, Jocelyn; KHADIYATOULAH, Fall. Les espaces de l'identité. Sainte Foy: Les Presses de l'Université Laval: 62-98.

Payne, J.(1991). Catalonia: Portrait of a Nation. Londres: Century.

PI-SunYer, O. (1985). «Catalan Nationalism: Some Theoretical and Historical Considerations». A: Tiryankian, Edward A.; Rogowski, Ronald (eds.). New Nationalisms of the Developed West. Boston, Alen \& Unwin: 254-76.

PiLON, A.(1985). Le coureur de bois moderne. Montmagny / Québec: Éditions Marquis Ltée.

Requejo, R. (2000). «El federalismo liberal y la calidad de las democracias plurinacionales. Déficits actuales y posibles mejoras». Revista Española de Ciencia Política, 3: 31-52.

Ribera MARiné, R. (1998). «Montserrat com a símbol». A: ABADIA DE MONTSERRAT, Montserrat al Llindar del Tercer Mil.lenni. Barcelona: Publicacions de l'Abadia de Montserrat: 108-119.

SMITH, Anthony D. (1991). Nation Identity. Londres: Penguin.

SWYNGEDOUN, E. (1999). «Modernity and Hybridity: Nature, Regenaracionismo, and the Porduction of Spanish Landscape, 1890-1930». Annals of the Association of American Geographers, 89(3): 443-65.

Toogood, M.; Meyers (1999). Banal Globalism: Images, Actions and Frames of Meaning and Action. Lancaster University: article de treball no publicat.

Tremblay, G.; PARÈS I MAICAS, M. (1990). Autonomie et mondialisation: Le Québec et la Catalogne à l'heure du libre-échange et de la Communauté Européenne. Sillery: Presses de l'Université du Québec.

Turgeon, L.; Létourneau, J.; Khadiyatoulah, F. (1997). Les espaces de l'identité. Sainte Foy: Les Presses de l'Université Laval.

URRY, J. (1995). Consuming Places. Londres: Routledge.

VAN HoRnE, W.A. (ed.) (1997). Global Convulsions: Race, Ethnicity and Nationlism at the End of the Twentieth Century. Albany: SUNY Press.

VILANOVA, S. (1981). L'econacionalisme: Una alternativa catalana dins una Europa ecològica. Barcelona: Editorial Blume.

Vicens Vives, J. (1995). Notícia de Catalunya. Barcelona: Edicions 62.

Walter, F. (1990). «The Evolution of Environmental Sensitivity 1750-1950». A: Brimblecombe, P.; Pfister, C. (eds.). The Silent Countdown. Essays in European Environmental History. Berlín: Springer-Verlag.

ZelLer, S. (1987). Inventing Canada: Early Victorian Science and the Idea of a Transcontinental Nation. Toronto: University of Toronto Press. 